\title{
Bioremediation of Oil Contaminated Soil by Biostimulation Method Using NPK Fertilizer
}

\author{
Bieby Voijant Tangahu*, Lukman Vyatrawan, Rima Nurmalasari, Februriyana Pirade \\ Environmental Engineering Department, Institut Teknologi Sepuluh Nopember, Surabaya, Indonesia \\ Email: *voijant@its.ac.id
}

How to cite this paper: Tangahu, B.V., Vyatrawan, L., Nurmalasari, R. and Pirade, F. (2017) Bioremediation of Oil Contaminated Soil by Biostimulation Method Using NPK Fertilizer. Open Access Library Journal, 4: e3791.

https://doi.org/10.4236/oalib.1103791

Received: June 30, 2017

Accepted: November 14, 2017

Published: November 17, 2017

Copyright ( 2017 by authors and Open Access Library Inc.

This work is licensed under the Creative Commons Attribution International License (CC BY 4.0).

http://creativecommons.org/licenses/by/4.0/

\section{Open Access}

\begin{abstract}
Petroleum contamination in the soil is known to reach the location of groundwater resources thereby potentially contaminating groundwater that is used as the primary source of clean water. Hydrocarbon compounds contained in the petroleum are also compounds that are most difficult to breakdown. One way of overcoming this problem is by bioremediation, which is a recovery of environmental condition by utilizing biological microorganism activity to reduce levels of toxicity of pollutant compounds. The research was conducted in laboratory scale for 30 days using biostimulation methods with NPK fertilizer as nutrient. Variations are done in the level of NPK fertilizer nutrients to the contaminated soil (control, $10 \%$, and $20 \%$ ). The parameters tested include the value of total petroleum hydrocarbons (TPH), temperature, $\mathrm{pH}$ and total microbial colonies contained in the contaminated soil samples. Results of research showed that the addition of nutrients is as much as $20 \%$ (w/w). Bioremediation was able to reduce $\mathrm{TPH}$ up to $4.23 \%$ (initially $8.37 \%$ TPH) in week 4 of the research. Addition of nutrition in the form of NPK fertilizer highly affects the TPH value degradation rate in oil-contaminated soil samples. Higher concentration of NPK fertilizer added leads to better degradation rate of $\mathrm{NPH}$ value
\end{abstract}

\section{Subject Areas}

Biological Materials

\section{Keywords}

Bioremediation, Biostimulation, Petroleum, Soil Pollution, NPK Fertilizer

\section{Introduction}

Petroleum contamination in the soil is a serious threat to human health. Petro- 
leum pollutes the soil and can reach the location of groundwater, lakes or other water sources which provide water for domestic and industrial needs, becoming a problem serious for areas that rely on groundwater as their main source of clean water needs [1]. One of the oil contaminants that were difficult to breakdown is hydrocarbon compound. When these compounds contaminate the soil surface, then these substances can evaporate, wash away by rain, infiltrate into the ground and then store as a toxic substance. Consequently, they may disrupt the soil ecosystem and the water cycle [2].

Naturally, the environment already has the ability to degrade pollutant compounds that enter into it through biological and chemical processes, but often the pollution load on the environment is greater than the speed of natural degradation process of contaminants. As a result, pollutants will accumulate, so human intervention along with existing technology is required to solve the pollution issue [3]. Addressing the problem of oil pollution in soil, there are several ways to resolve this. One way is by bioremediation.

Bioremediation is an effort to recover the environment by using biological activity of microbes to degrade and decrease the toxicity of various pollutant compounds. This is because, in overcoming problems in the same environment, bioremediation is known to be more cost-effective than the implementation of other technologies such as incineration and containment [4].

Many factors can influence the success of bioremediation. The most important environmental factors in bioremediation include moisture, $\mathrm{pH}$, and temperature [4]. The addition of nutrients is known to increase the activity of indigenous microorganisms, including hydrocarbon degrading organisms. The addition of nutrients in two treatments (biostimulation and combinations bioaugmentation-biostimulation) has contributed to increased degradation of hydrocarbons that will be visible in the first three weeks of the incubation process [5]. There are two approaches that can be used in oil spill bioremediation: (a) bioaugmentation, where decomposing microorganisms are added to complement the existing microbial populations, and (b) biostimulation, where growth of indigenous hydrocarbon-degrading is stimulated by adding nutrients or altering the habitats.

A study was previously done by reference [6] about bioremediation of oilcontaminated soil by biostimulation using combined compost. In that study, efficiency result obtained of total petroleum hydrocarbon (TPH) degradation reaches $77.3 \%$ during 30 days. Seeing, the result of that study, this one will conduct bioremediation by biostimulation method using other nutrients (NPK fertilizer) to analyze the capability of existing microorganisms in soil in degrading TPH level in contaminated soil.

\section{Research Methods}

\subsection{Tools and Materials Preparation}

In this study necessary tools and materials are needed in sustainability research. 
The tools used are container glass reactor, 20 mesh sieve, a small shovel, soil tester T-350, analytical balance, oven, desiccator, colony counters, autoclave, and incubators and other tools necessary for analysis.

Materials prepared include building sand, motor oil, NPK fertilizer, n-hexane solution for analysis (EMSURE ${ }^{\circledR}$ ACS, Reag. Ph Eur), anhydrous $\mathrm{Na}_{2} \mathrm{SO}_{4}$, Whatman filter paper, nutrient agar (NA) and materials necessary to complement the analysis.

\subsection{Preparation of Polluted Media (Spiked Soil)}

The sample used in this study is the waste made in the form of a mixture of building sand and motor oil with concentration set at $12 \%(\mathrm{w} / \mathrm{w})$. Previously, the building sand is dried under the sun for one day, then sifted using 20 mesh sieve to separate sand stone structure and other small pebbles. The results of sieved sand and motor oil are weighed using analytical balance and then mixed and allowed to stand 2 - 3 days until the motor oil and building sand are evenly mixed (Figure 1).

\subsection{Analysis of Total Petroleum Hydrocarbons (TPH) Initial Value}

TPH value measurement using gravimetric methods are adapted to US EPA821-R-98-002 16641999 Method of Measurement of the value of the initial TPH done triplo then averaged to get the average value fairly accurate to initial TPH in soil samples.

Starting by weighing as much as 5 grams of soil samples that have been made, $50 \mathrm{ml} \mathrm{n}$-hexane is then added and stirred for \pm 10 minutes until the color of the solution becomes brownish. The addition of $n$-hexane aims to bind the oil content contained in soil samples. Separate samples of soil with a solution of n-hexane which has mixed oil by filtration using Whatman filter paper. Filtering process will produce residues in the form of soil and the filtrate a solution of n-hexane mixed with petroleum.

The filtrate from first filtering result was added 2 spoon spatula or about 2.5 grams of Sodium Sulfate $\left(\mathrm{Na}_{2} \mathrm{SO}_{4}\right)$ anhydride then stirred for \pm 10 minutes. The addition of Sodium Sulfate $\left(\mathrm{Na}_{2} \mathrm{SO}_{4}\right)$ anhydrate aims to eliminate the water content still contained in the filtrate. The filtrate was then filtered back using paper strain (Figure 2).

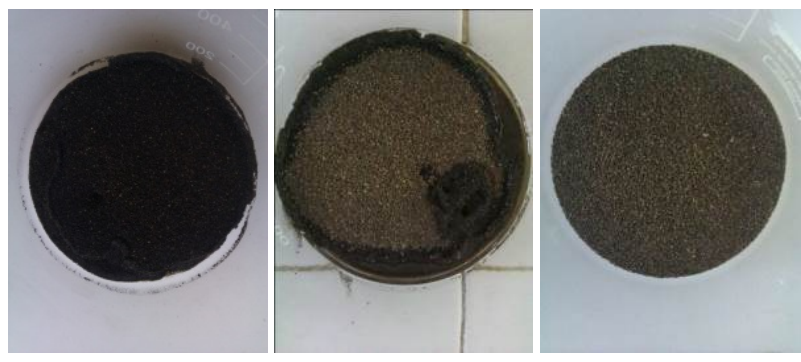

Figure 1. Color change of sand building before and after mixed with motor oil. 


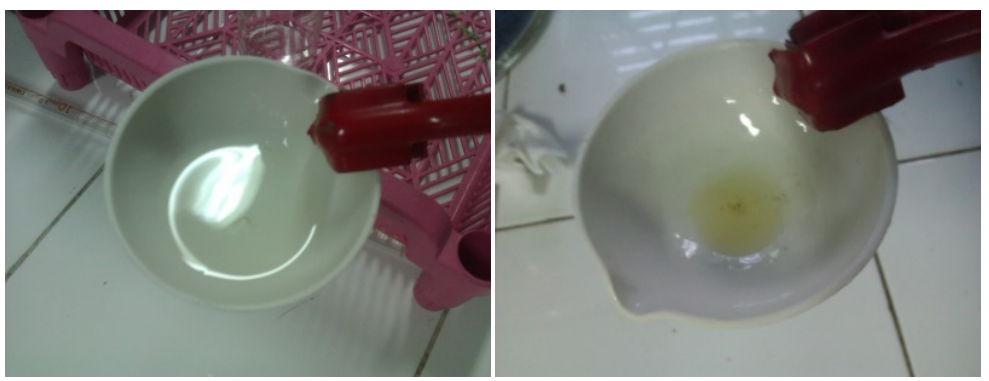

Figure 2. Residue before and after oven $105^{\circ} \mathrm{C}$ for \pm 1 hour.

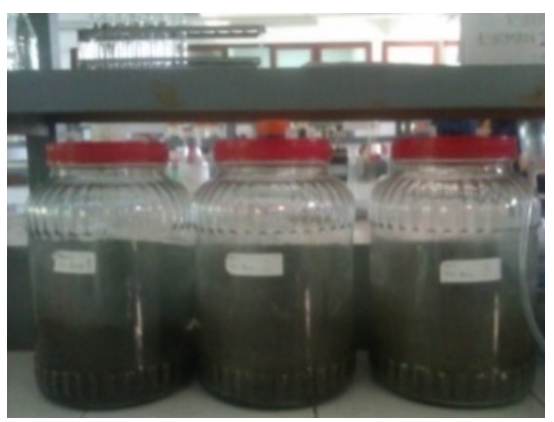

Figure 3. Bioremediation reactor.

The filtrate of second filtering results is placed in a porcelain cup (porcelain cup has weighed the initial weight) and then inserted into a preheated oven \pm $105^{\circ} \mathrm{C}$ for 1 hour. After completion of the oven process, porcelain cup containing residues is put in dessicator for \pm 15 minutes and then weighed on analytical balance; TPH value calculated is contained in the soil samples with the following formula:

$$
\% \mathrm{TPH}=\frac{\text { Reidue Weight }(\text { gram })}{\text { Sample Weight }(\text { gram })} \times 100 \%
$$

Description:

Residue Weight $=[$ Grail Weight + Residue $]-[$ Empty Porcelain Cup Weight $]$

Sample Weight $=$ Initial Soil Sample Weight were analyzed $(\mathrm{g})$

After analysis with gravimetric method, obtained an initial average concentration of TPH in soil samples contaminated by $8.37 \%$.

\subsection{Implementation of Bioremediation}

Implementation of the main research was done in a laboratory for 30 days using biostimulasi. Nutrients are used in this research was NPK fertilizer. The addition of NPK fertilizer aims to provide nutrients for bacteria as sources of nitrogen and phosphorus [7]. Carbon source itself is obtained from the hydrocarbon content of the pollutant.

There are two variations used in bioremediation, including the addition of nutrients to the soil $(0 ; 10 \%$ and $20 \%)$. The addition of nutrients as much as $10 \%$ means NPK fertilizer is added as much as $1 / 10$ of the total weight of the soil sample used (grams per gram) (Figure 3 ). 


\section{Results and Discussion}

\subsection{Value of Total Petroleum Hydrocarbons (TPH) Bioremediation}

$\mathrm{TPH}$ is one of the most important parameters in determining the success rate of the bioremediation process. TPH parameters is done measuring every single week for 30 days by gravimetric method. Result of TPH value measurement during the bioremediation process can be seen in Table 1.

In Figure 4, the chart impairment TPH that occur between the variations addition of nutrients showed a different decrease. The biggest decrease TPH occurred in the early research $(\mathrm{H}-0)$ to week 2 of the research. In Figure 4 , the chart impairment TPH variations that occur between the addition of nutrients showed a decrease different. TPH biggest decrease occurred in the early research $(\mathrm{H}-0)$ to week 2 of the study. In the next weeks still happen which tends to decrease slowly. At week 4 the analysis, there is an increase that is small enough (around $0.03 \%$ ) between TPH value in the addition of nutrient variation of $20 \%$. This can reduce inequality due to the influence of the sampling point when the $\mathrm{TPH}$ analysis is conducted.

\subsection{Bioremediation $\mathrm{pH}$}

Measurement of $\mathrm{pH}$ in soil samples aims to identify and control the $\mathrm{pH}$ value,

Table 1. Soil sample TPH value for bioremediation process.

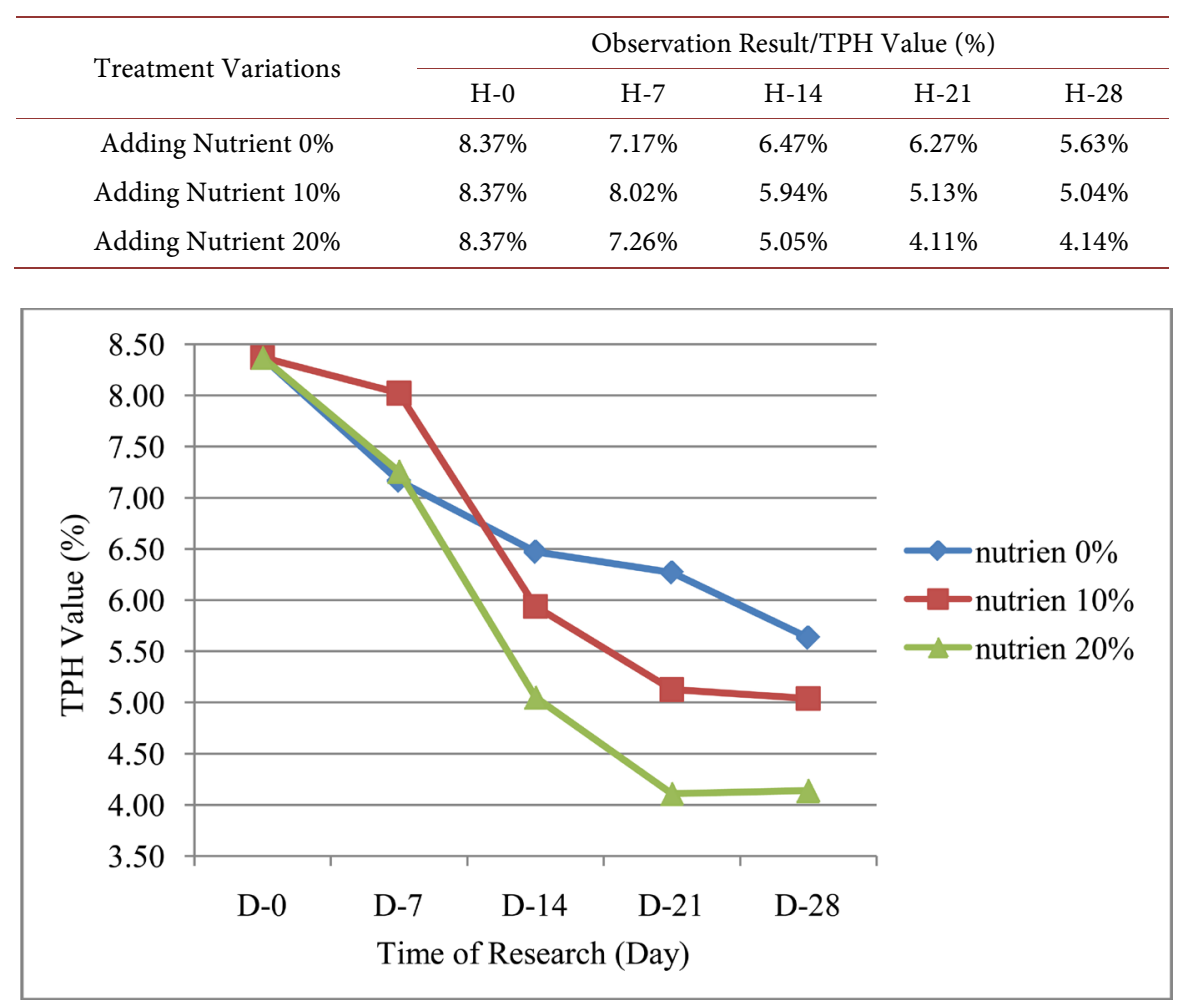

Figure 4. Parameter value total petroleum hydrocarbons (TPH) during the process of bioremediation. 
and can determine the effect of $\mathrm{pH}$ on the process of biodegradation of petroleum hydrocarbons on any treatment variations. $\mathrm{PH}$ measurement is done once every 3 days for 30 day. Measurements were made using a soil tester T-350. This tool works automatically in detecting the $\mathrm{pH}$ value and temperature values in the sample (Figure 5).

The growth of microorganisms increases when the $\mathrm{pH}$ in the range of $6-9$ [8]. During this research, the $\mathrm{pH}$ value in all variations of the addition of nutrients figures show a fairly stable, which is located at number 7 .

\subsection{Bioremediation Temperature}

The temperature can be defined as the degree or level of heat. Temperature measurement in soil samples also aims to identify and control the temperature, and can find out the effect of temperature on the process of biodegradation of petroleum hydrocarbons in every variation treatment.

Temperature measurement is performed in conjunction with the measurement of $\mathrm{pH}$, which is every 3 days for 30 days. Measurements were made using a soil tester T-350 can also be read the temperature value of soil. Temperature values of soil samples during the study can be seen in Figure 6 .

In this research, the ground temperature ranges between $27^{\circ} \mathrm{C}-31^{\circ} \mathrm{C}$. It means that the temperature of soil shows the number corresponding to the

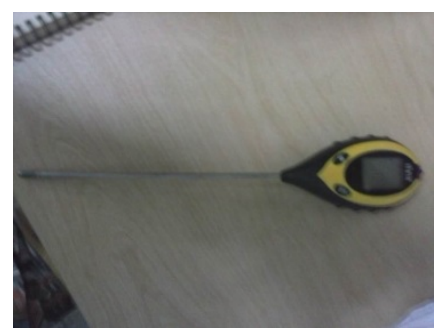

Figure 5. Soil tester T-350.

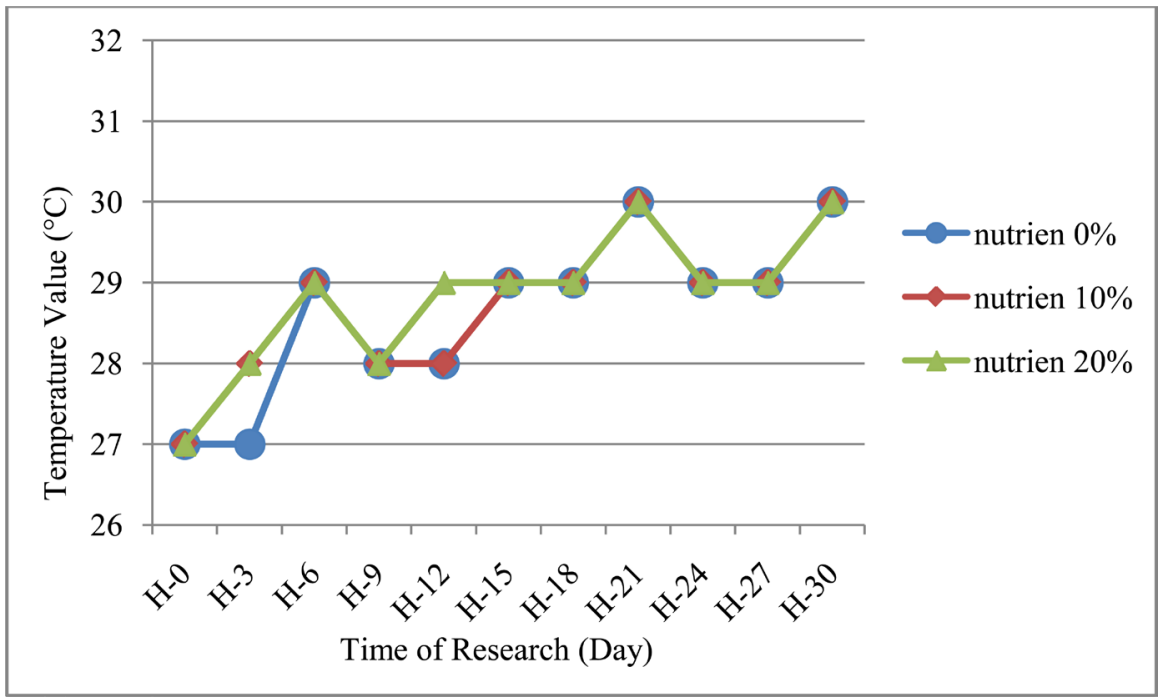

Figure 6. Temperature value for bioremediation process. 
optimum temperature for microorganisms both in growth and degrade soil samples decrease and increase in temperature can also be affected by environment conditions (weather) at the sites. Besides that, oxygen supply into the reactor causes higher energy produced from microorganism activity, thus resulting in higher environment temperature. High temperatures can decrease oil viscosity and speed up degradation process.

The optimum temperature for almost all soil microorganisms generally ranges fro $10^{\circ} \mathrm{C}$ to $40^{\circ} \mathrm{C}$. While the optimum temperature required for the growth of bacteria in biodegradation Oil sludge is $20^{\circ} \mathrm{C}-30^{\circ} \mathrm{C}$. Nevertheless, degradation activity by bacteria will decrease with the decrease in temperature, thus causing the total amount of degraded oil less.

\subsection{Total Colonies of Microbes}

Measurement of total colonies of microbes performed at baseline (day 0) and at the end research (day 30). According to reference [9], the cup count method (plate count) the best number of colonies that can calculated to range between 30 - 300 microbes per $\mathrm{mL}$ or per gram sample. If at all the dilutions produced less than 30 colonies of microbes on a petri dish means dilution carried too high, and vice versa. By therefore, should be chosen level of dilution that produce between 30 - 300 colonies.

Soil samples of 10 grams put into erlenmeyer containing $150 \mathrm{ml}$ of distilled water then shake it for 1 hour. The sample is to be used to calculate the total colonies of microbes in soil samples. Take $1 \mathrm{ml}$ with a sterile pipette measure NA media pour into petri dishes. This parameter testing performed aseptically (near with fire) which aims to minimize the increase in microbes from the external environment to the media.

After settling \pm 15 minutes, a petri dish containing NA media and the sample put into an incubator at $37^{\circ} \mathrm{C}$ for 24 hours to calculate the total microbial colonies growing colony counter. The observation of total microbial colonies at the beginning and end of the study can be seen in Table 2 .

At the beginning of research, a total of colonies counted as many as 101 colonies without any dilution. Sample without dilution used because previous tests have been conducted that together with several dilutions (10 - 1 to $10-5)$, but found the number total colony count not yet fulfill the criteria and reference [9], the total microbial colonies between the range of $30-300$ colonies per gram

Table 2. Calculation results total colonies of microbes during bioremediation process.

\begin{tabular}{ccc}
\hline Time of research & Variation in treatment & Total Colony of Microbes \\
\hline Beginning of research (D-0) & $\begin{array}{c}\text { Contaminated soil by oil } \\
\text { concentration of } 12 \%(\mathrm{w} / \mathrm{w})\end{array}$ & $101 \times 10^{\circ}$ \\
End of research (D-30) & Nutrien 0\% & $36 \times 10^{0}$ \\
& Nutrien 10\% & $41 \times 10^{0}$ \\
& Nutrien $20 \%$ & $66 \times 10^{0}$ \\
\hline
\end{tabular}


or per ml sample.

\section{Conclusion}

Based on the research that has been done, it can be conclude that the addition of NPK fertilizer nutrients on bioremediation processes affect the results impairment of TPH in soil. The addition of NPK fertilizer by $20 \%$ is able to lower TPH content of up to $4.23 \%$ (from the beginning of $8.37 \% \mathrm{TPH}$ ).

\section{References}

[1] Atlas, R.M. and Bartha, R. (1998) Microbial Ecology: Fundamentals and Applications. Addison-Wesley Publishing Company, London.

[2] Karwati (2009) Degradasi Hidrokarbon pada Tanah Tercemari Minyak Bumi dengan Isolat A10 dan D8. [Degradation of Hydrocarbons in the Petroleum-Contaminated Soil with Isolates A10 and D8]. Institut Pertanian Bogor, Skripsi, Bogor.

[3] Nugroho, A. (2006) Biodegradasi Sludge Minyak Bumi dalam Skala Mikrokosmos. [Biodegradation of Petroleum Sludge in Microcosmic Scale]. Jurnal Makara Tekno$\log , 10,82-89$.

[4] Cookson, J.T. (1995) Bioremediation Engineering. Mc-Graw Hill, New York.

[5] Makadia, T.H., Adetutu, E.M., Simons, K.L., Jardine, Da., Sheppard, P.J. and Ball, A.S. (2011) Re-Used of Remediated Soils for Bioremediation of Waste Oil Sludge. Journal of Environmental Management, 92, 866-871. https://doi.org/10.1016/j.jenvman.2010.10.059

[6] Zhyahrial, F.F., Rahayu, Y.S. and Yuliani (2014) Bioremediasi dengan Teknik Biostimulasi Tanah Tercemar Minyak Bumi dengan Menggunakan Kompos Kombinasi Limbah Media Jamur Tiram Putih (Pleurotus ostreatus) dan Azolla. [Bioremediation with Biostimulation Technique of Petroleum-Contaminated Soil Using White Oyster Mushroom (Pleurotus ostreatus) Media Waste and Azolla Compost Combinations]. LenteraBio Journal, 3, 141-146.

[7] Hafiluddin (2011) Bioremediasi Tanah Tercemar Minyak dengan Teknik Bioaugmentasi dan Biostimulasi. [Bioremediation of Oil Polluted Soils by Bioaugmentation Technique and Biostimulation]. Jurnal Embryo, 8, 47-52.

[8] Eweis, J.B., Ergas, S.J., Chang, D.P. and Schoroeder, E.D. (1998) Bioremediation Principles. Mc-Graw Hill, New York.

[9] Cappuccino, J.G. and Sherman, N. (2013) Microbiology-A Laboratory Manual. 10th Edition, Benjamin/Cunnings Science Publishing, California. 